\title{
POLA DISTRIBUSI KOMODITAS KENTANG DI KABUPATEN BANDUNG, JAWA BARAT
}

\author{
Adang Agustian ${ }^{1}$ \\ Henny Mayrowani ${ }^{1}$ \\ ${ }^{1}$ Pusat Analisis Sosial Ekonomi dan Kebijakan Pertanian (PSE-KP), Bogor \\ E-mail: adangagustian@yahoo.co.id
}

\begin{abstract}
The study was conducted in Bandung District, West Java on 2005. Primary data were collected through interview with potato's farmers (who grow Granola variety and Atlantic variety) and potato's trader. Method of analysis is quantitative and qualitative analysis. The results of the study are as follow: (1) There are two kinds of marketing pattern of potato in West Java: (a) Marketing pattern of Granola variety which is distributed to several market especially central market. Majority of Granola variety is for household consumption; and (b) Partnership pattern between farmer's group or farmers with PT Indofood FM for Atlantic variety. Most of this variety is used as a raw material for food processing industries; (2) Most of potato's farmers sell their product to village collectors, and potato's farmers who have large scale of potato's farm can directly sell to district traders and central market. (3) Atlantic variety were distributed through Farmer's Group to Partner Company.
\end{abstract}

Key words: marketing pattern, distribution pattern, partnership

\section{PENDAHULUAN}

Komoditas kentang merupakan salah satu komoditas hortikultura unggulan di Jawa Barat (Dinas Pertanian Tanaman Pangan Jabar, 2006). Jenis kentang yang banyak diusahakan petani di Kabupaten Bandung adalah kentang Granola, dan pada petani yang menjalin kerjasama dengan PT Indofood FM melalui mediasi kelompok tani mengusahakan jenis kentang Atlantik. Rataan pengusahaan lahan kentang berkisar antara $0,5-1,5$ hektar.

Dalam pemasaran komoditas hortikultura secara umum terdapat beberapa pihak selain produsen dan konsumen, yaitu lembagalembaga perantara yang menghubungkan sentra produksi dan sentra konsumsi dengan melakukan berbagai aktivitas yang memberikan nilai guna bagi produk yang dipasarkan. Jumlah dan jenis lembaga perantara tersebut secara horizontal dan vertikal sangat dipengaruhi oleh jenis komoditas yang dipasarkan, fasilitas pemasaran yang tersedia dan keinginan pasar sasaran (konsumen) yang hendak dicapai. Semakin banyak dan kompleks permintaan konsumen dan semakin banyak perubahan bentuk dari komoditas yang dipasarkan sebelum sampai di tangan konsumen, maka akan semakin banyak pula menuntut kehadiran para lembaga perantara.

Beberapa permasalahan dalam sistem pemasaran komoditas hortikultura secara 
umum termasuk komoditas kentang yang dihadapi oleh para pelaku adalah tingginya biaya pemasaran dan pembagian balas jasa yang adil bersifat asimetris, bahkan balas jasa tersebut atas fungsi pemasaran lebih besar mengelompok pada pedagang besar, sementara petani dan pedagang pengumpul bagiannya kecil. Dengan demikian, sebaran margin perdagangan cenderung tidak merata atau tidak efisien dan lebih mengelompok pada pedagang besar/bandar, supplier, dan sebagainya. Mahalnya biaya pemasaran komoditas hortikultura merupakan akibat dari ketidakefisienan yang disebabkan oleh panjangnya rantai pemasaran. Masalah lainnya adalah terkait fluktuasi harga merupakan masalah yang paling sering dihadapi para petani sebagai produsen hortikultura.

Oleh karena itu, pengembangan komoditas hortikultura termasuk komoditas kentang disamping berupaya dalam meningkatkan kuantitas produksinya yang diiringai dengan perbaikan kualitasnya sesuai tuntutan konsumen/pasar secara luas juga diupayakan perbaikan dalam hal pemasarannya melalui perluasan tujuan pemasaran dan kerjasama kemitraan.

Tulisan ini bertujuan untuk menganalisis pola pemasaran komoditas kentang serta margin pemasaran yang diraih pelaku pemasaran.

\section{METODE PENELITIAN}

\section{Kerangka Pemikiran}

Sistem pemasaran memiliki peran yang sangat penting dalam mendistribusikan komoditas pertanian dari pusat produksi ke pusat konsumsi. Dalam pergerakan komoditas ini, maka keberadaan kelembagaan pemasaran menjadi bagian penting di dalamnya
(Maliati, 2002). Kelembagaan pemasaran yang berperan dalam memasarkan komoditas pertanian hortikultura dapat mencakup petani, pedagang pengumpul, pedagang perantara/grosir dan pedagang pengecer. (Kuma'at, 1992). Kelembagaan pemasaran lainnya yang berperan dalam pemasaran komoditas hortikultura adalah berupa pasar tradisional, pasar modern dan pasar industri.

Sementara itu, secara umum sistem pemasaran komoditas pertanian termasuk hortikultura masih menjadi bagian yang lemah dari aliran komoditas. Masih lemahnya pemasaran komoditas pertanian tersebut karena belum berjalan secara efisien (Irawan, et.al, 2001). Suatu sistem pemasaran yang efisien harus mampu memenuhi dua persyaratan yaitu: (1) mengumpulkan hasil pertanian dari produsen ke konsumen dengan biaya serendah-rendahnya; dan (2) mampu mendistribusikan pembagian balas jasa yang adil dari keseluruhan harga konsumen akhir kepada semua pihak yang terlibat mulai dari kegiatan produksi hingga pemasaran.

Secara empiris di lapangan seringkali dijumpai bahwa para petani produsen tampaknya tetap saja menghadapi fluktuasi harga terutama saat panen, dan para pedaganglah yang dapat lebih akses untuk dapat memperoleh harga yang lebih tinggi tersebut terutama bagi pasar modern. Untuk dapat menjangkau pasar modern tidaklah mudah, banyak persyaratan yang mesti dipenuhi dan persyaratan yang ketat ini hanya cenderung dapat dipenuhi oleh pedagang seperti supplier untuk memasok pasar modern. Bahkan untuk bisa menjual ke supplier secara langsung, para petani masih merasakan kesulitan misalnya dalam hal pemenuhan kontinyuitas dan sistem pemba- 
yaran yang bertenggang waktu (misalnya antara 7-15 hari).

Oleh karena itu, peningkatan produksi komoditas pertanian termasuk komoditas hortikultura kentang perlu diiringi dengan perbaikan pada sistem pemasarannya, sehingga pihak petani sebagai produsen komoditas ini diharapkan dapat memperoleh bagian harga yang memadai bagi peningkatan usahataninya.

\section{Lokasi Penelitian dan Jenis Data yang Dikumpulkan}

Penelitian ini dilaksanakan di Kecamatan Pangalengan dan Lembang Kabupaten Bandung Jawa Barat, tahun 2005. Pemilihan lokasi didasarkan atas potensi (sentra) komoditas kentang. Jenis data yang dikumpulkan meliputi data primer dan sekunder. Data primer dikumpulkan melalui wawancara langsung dengan kuesioner terstruktur terhadap responden petani, pedagang pengumpul, pedagang besar/agen/ suppplier, pedagang di pasar tradisional, dan pasar moderen (supermarket). Jumlah sampel petani adalah sebanyak 40 petani, yang mencakup petani kentang granola yang merupakan para petani yang melakukan pemasaran secara mandiri, dan petani kentang atlantik yang melakukan kerjasama dengan PT. Indofood FM. Untuk data sekunder dikumpulkan dari berbagai instansi/lembaga yang terkait dengan pengembangan dan pemasaran komoditas kentang.

\section{Analisis Data}

Data yang terkumpul dianalisis secara kuantitatif dan deskriptif kualitatif. Untuk menganalisis pola pemasaran komoditas kentang akan dianalisis secara kualitatif yang akan diuraikan meliputi tujuan/alur pemasaran dan struktur pasar komoditas kentang. Selanjutnya untuk analisis margin pemasaran komoditas kentang diuraikan sebagai berikut:

Margin pemasaran merupakan perbedaan harga yang diterima oleh petani dengan harga yang dibayarkan oleh konsumen. Untuk menganalisis margin pemasaran dalam penelitian ini, data harga yang digunakan adalah harga di tingkat petani dan harga di tingkat lembaga pemasaran, sehingga dalam perhitungan margin pemasaran digunakan rumus:

$$
\mathbf{M m}=\mathbf{P r}-\mathbf{P f}
$$

dimana:

$\mathrm{Mm}=$ margin pemasaran di tingkat petani

$\operatorname{Pr}=$ harga di tingkat kelembagaan pemasaran tujuan pemasaran dari petani

Pf = harga di tingkat petani

Margin pada setiap tingkat lembaga pemasaran dapat dihitung dengan jalan menghitung selisih antara harga jual dengan harga beli pada setiap tingkat lembaga pemasaran. Dalam bentuk matematika sederhana dirumuskan:

$$
\mathbf{M m i}=\mathbf{P s}-\mathbf{P b}
$$

dimana:

$\mathrm{Mmi}=$ margin pemasaran pada setiap tingkat lembaga pemasaran

Ps = harga jual pada setiap tingkat lembaga pemasaran

$\mathrm{Pb}=$ harga beli pada setiap tingkat lembaga pemasaran

Karena dalam margin pemasaran terdapat dua komponen, yaitu komponen 
biaya dan komponen keuntungan lembaga pemasaran, maka:

$$
\begin{aligned}
& \operatorname{Mm}=\mathbf{c}+\dot{\eta} \\
& \mathbf{P e}-\mathbf{P f}=\mathbf{c}+\dot{\eta} \\
& \mathbf{P f}=\mathbf{P e}-\mathbf{c}-\dot{\eta}
\end{aligned}
$$

dimana:

$$
\begin{aligned}
\mathrm{c}= & \text { biaya pemasaran } \\
\dot{\eta}= & \text { keuntungan lembaga pemasaran (net } \\
& \text { margin pemasaran). }
\end{aligned}
$$

\section{HASIL PENELITIAN DAN PEMBAHASAN}

\section{Perkembangan Luas Panen dan Produksi Kentang}

Secara umum terdapat dua jenis varietas kentang yang diusahakan petani di Kabupaten Bandung, yaitu kentang Granola dan Atlantik. Kentang granola diusahakan oleh para petani pada umumnya secara mandiri dengan rantai pemasaran melalui pedagang pengumpul, dan Bandar, untuk berbagai tujuan pasar baik pasar induk, pasar tradisional, maupun super market. Untuk jenis kentang atlantik diusahakan oleh petani melalui kemitraan usaha dalam hal pemasaran dengan PT. Indofood FM dengan mediasi pedagang pengepul atau kelompok tani.

Sentra produksi kentang di Jawa Barat berada pada wilayah dataran tinggi, yang terkonsentrasi di beberapa Kabupaten yaitu Kabupaten Bandung, Garut, Majalengka, serta Cianjur. Sebaran daerah sentra produksi cukup tinggi yaitu di Kabupaten Bandung utamanya di Kecamatan Pangalengan, Ciwidey, dan Lembang dengan pola pemasaran yang beragam untuk tujuan pasar induk, pasar tradisional, supermarket dan industri pengolahan (PT. Indofood Fritolay Makmur).

Bila diperhatikan perkembangan luas panen kentang di Jawa Barat pada periode 1999-2005 menunjukkan penurunan sebesar 5,41 persen/tahun, nampak dalam Tabel 1. Penurunan tersebut juga berimbas pada penurunan produksinya sebesar 3,54 persen/tahun, dan penurunan produksi ini sedikit lebih rendah dibanding penurunan areal panennya sebagai akibat produktivitas kentang yang tampaknya masih bisa sedikit meningkat sebesar 1,93 persen/tahun. Pada tahun 2005, areal panen kentang di Jawa Barat mencapai 17.744 hektar, dengan tingkat produksi dan produktivitasnya mencapai 359.891 ton dan 202,82 ku/ha. Seperti halnya diketahui, bahwa varietas kentang yang dominan dibudidayakan oleh petani di Jawa Barat adalah Granola, sedangkan kentang Atlantik masih terbatas dibudidayakan oleh petani dan itupun seluruhnya ditanam oleh petani yang bermitra dengan industri pengolahan keripik kentang seperti PT. Indofood FM.

Sementara itu, di lokasi penelitian Kabupaten Bandung juga menampakkan perkembangan areal kentang yang sama dengan di Propinsi Jawa Barat secara umum. Areal panen kentang di Bandung dalam kurun waktu 1999-2005 menunjukkan penurunan sebesar 8,31 persen/tahun, yang diikuti oleh penurunan produksinya sebesar 5,62 persen, namun produktivitasnya masih bisa meningkat sebesar 3,15 persen/tahun. Pada tahun 2005, areal panen kentang di Kabupaten Bandung sebesar 10.851 hektar dengan tingkat produksi dan produktivitasnya sebesar 257.116 ton dan $236,95 \mathrm{ku} / \mathrm{ha}$. 
Tabel 1. Perkembangan Luas Tanam, Luas Panen, Produksi dan Produktivitas Kentang di Propinsi Barat dan Lokasi Penelitian, 1999-2005.

\begin{tabular}{|c|c|c|c|c|c|c|c|c|}
\hline \multirow[t]{2}{*}{ Tahun } & \multicolumn{4}{|c|}{ Jawa Barat } & \multicolumn{4}{|c|}{ Kab. Bandung } \\
\hline & $\begin{array}{l}\text { Luas } \\
\text { Tanam } \\
\text { (Ha) }\end{array}$ & $\begin{array}{c}\text { Luas } \\
\text { Panen } \\
\text { (Ha) }\end{array}$ & $\begin{array}{l}\text { Produksi } \\
\text { (Ton) }\end{array}$ & $\begin{array}{c}\text { Produk- } \\
\text { tivitas } \\
\text { (ku/ha) }\end{array}$ & $\begin{array}{l}\text { Luas } \\
\text { Tanam } \\
\text { (Ha) }\end{array}$ & $\begin{array}{l}\text { Luas } \\
\text { Panen } \\
\text { (Ha) }\end{array}$ & $\begin{array}{l}\text { Produksi } \\
\text { (Ton) }\end{array}$ & $\begin{array}{c}\text { Produk- } \\
\text { tivitas } \\
\text { (ku/ha) }\end{array}$ \\
\hline 1999 & 22.684 & 22.813 & 426.864 & 187,11 & 15.283 & 15.686 & 308.990 & 196,98 \\
\hline 2000 & 25.263 & 28.695 & 509.972 & 177,72 & 17.913 & 21.368 & 366.714 & 171,62 \\
\hline 2001 & 24.492 & 23.414 & 414.431 & 177,00 & 17.566 & 16.493 & 292.389 & 177,28 \\
\hline 2002 & 22.748 & 19.896 & 363.327 & 182,61 & 16.171 & 13.184 & 227.841 & 172,82 \\
\hline 2003 & 17.819 & 20.491 & 390.065 & 190,36 & 11.117 & 12.435 & 223.134 & 179,44 \\
\hline 2004 & 15.213 & 21.092 & 418.230 & 198,29 & 10.140 & 13.455 & 261.388 & 194,27 \\
\hline 2005 & 17.969 & 17.744 & 359.891 & 202,82 & 10.995 & 10.851 & 257.116 & 236,95 \\
\hline $\begin{array}{c}\text { Perkembangan } \\
\text { (persen/thn) }\end{array}$ & $-7,00$ & $-5,41$ & $-3,54$ & 1,93 & $-8,79$ & $-8,31$ & $-5,62$ & 3,15 \\
\hline
\end{tabular}

Sumber:

Dinas Pertanian Tanaman Pangan Jabar (2005).

Dinas Pertanian Kab. Bandung (2005).

BPS-Jawa Barat, Jawa Barat Dalam Angka (2006).

Fluktuatifnya luas areal panen komoditas kentang terutama jenis granola antara lain disebabkan: (1) meningkatnya harga input baik bibit, pupuk, serta pestisida dan fungisida; (2) serangan penyakit yang cukup beragam seperti Penyakit busuk daun (Phytoptora infestans), Penyakit bercak kuning, Penyakit layu fusarium, Penyakit layu bakteri, Penyakit virus daun menggulung, Penyakit virus kentang mozaik, Penyakit nematoda bengkak akar, (3) serangan hama seperti kutu daun, hama Trips, penggerek ubi kentang, (4) harga kentang relatif stabil bahkan cenderung menurun (granola), akibatnya petani melakukan pilihan jenis tanaman, sistem tanam, dan pola tanam tidak hanya didasarkan pertimbangan teknis produksi namun juga telah didasarkan ekpektasi akan harga komoditas apa yang paling menguntungkan. Faktor-faktor itulah yang menjadikan perkembangan luas areal panen kentang menjadi cukup dinamis.

\section{Perkembangan Harga Komoditas Kentang}

Bila disimak pada Tabel 2, bahwa perkembangan harga bulanan komoditas kentang tahun 2003 di sentra produksi kentang seperti di Pangalengan (Bandung) relatif berfluktuasi antar bulannya. Harga kentang relatif rendah (dibawah Rp 2.000/kg) yaitu sekitar bulan Pebruari s/d Mei dengan kisaran harga antara $\mathrm{Rp} 1.330 / \mathrm{kg} \quad-\mathrm{Rp} 1.629 / \mathrm{kg}$. Relatif rendahnya harga kentang pada bulan-bulan tersebut akibat serentaknya panen pada pertanaman kentang musim penghujan. Selanjutnya harga kentang mulai merangkak naik dan puncaknya sekitar bulan Oktober (Rp 2.849/kg) yaitu menjelang hari Raya Idul Fitri. Harga kentang juga cukup tinggi pada setiap tahun baru dan Imlek yaitu bulan Januari (Rp2.813/kg). 


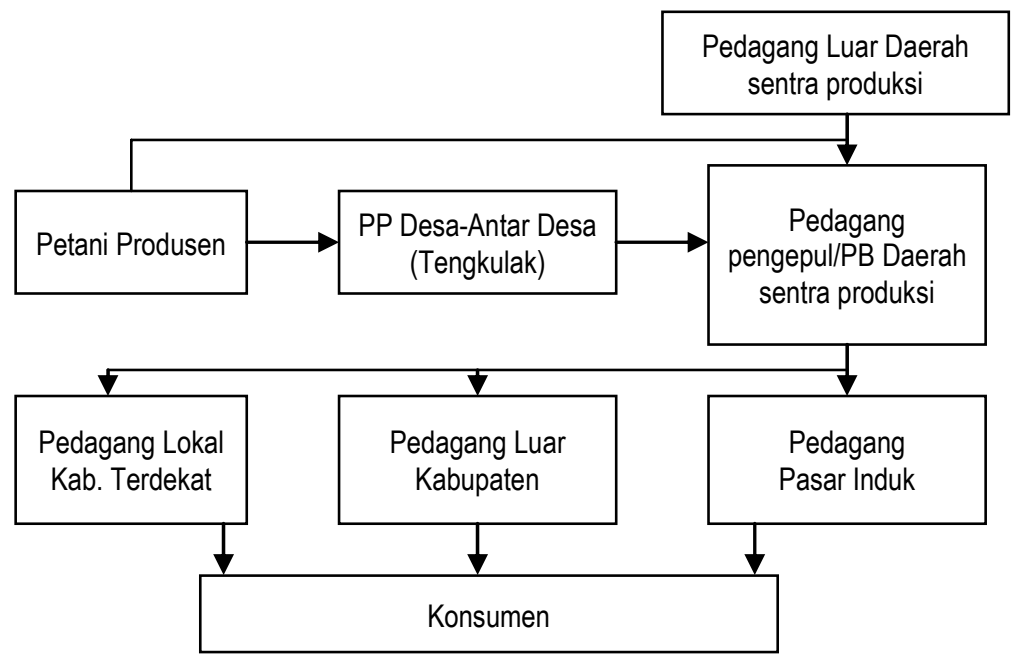

\section{Gambar 1. Saluran Tataniaga Kentang di Kabupaten Bandung Jawa Barat, Tahun 2006}

\section{Sumber: Dinas Pertanian Tanaman Pangan Propinsi Jawa Barat, 2005}

Selanjutnya, perkembangan harga bulanan kentang tahun 2003 di Pasar Induk Caringin Bandung tampaknya menunjukkan pada bulan-bulan tertentu disparitasnya relatif lebih tinggi dibanding dengan harga di sentra produksinya (bulan September s/d Desember), namun pada bulan-bulan tertentu harganya relatif tidak jauh berbeda (bulan Juli, Agustus). Secara rataan, harga di Pasar Induk Caringin relatif sama dengan harga di sentra produksi kentang seperti dengan harga di Pangalengan. Hal ini dapat terjadi karena terkait suplai kentang yang ada di PI Caringin Bandung. Seringkali, beberapa daerah sentra kentang seperti Dieng-Wonosobo telah panen, dan produknya secara dominan masuk ke PI Caringin. Disisi lain, sentra produksi kentang seperti di Jawa Barat baru menjelang panen, maka harga kentang di sentra produksi Jawa Barat cenderung relatif sama dengan harga kentang di PI Caringin Bandung.
Sementara itu, rataan harga pasar bulanan tahun 2004 untuk komoditas kentang di Kabupaten Bandung mencapai Rp $2.613 / \mathrm{kg}$. Terlihat bahwa secara umum harga kentang bergerak dari Rp 2.500/kg hingga ke Rp3.250/kg. Harga kentang tertinggi pada bulan Juni-Juli yaitu Rp 2.750 dan Rp $3.250 / \mathrm{kg}$.

Pada tahun 2005, harga kentang di pasaran Bandung relatif lebih tinggi lagi. Harga kentang tertinggi terjadi pada bulan Januari-Pebruari yaitu sekitar Rp 3.750/kg Rp 4.000/kg. Namun harga kentang sempat jatuh hingga level $\mathrm{Rp} 2.250 / \mathrm{kg}$ di bulan Maret, namun bulan selanjutnya terus mengalami peningkatan.

\section{Pola Pemasaran Komoditas Kentang}

1. Tujuan Pemasaran Kentang 


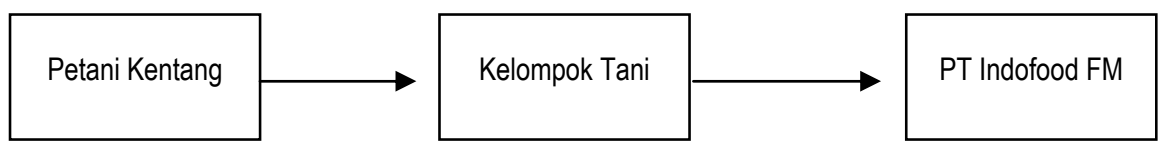

\section{Gambar 2. Alur Pemasaran Kentang Atlantik pada Petani yang Menjalin Kemitraan dengan PT. IFM di Kabupaten Bandung - Jawa Barat, Tahun 2006}

Berdasarkan temuan di lapangan terdapat dua pola saluran pemasaran komoditas kentang yang masih berjalan di Jawa Barat, yaitu : (1) Pola pemasaran untuk komoditas kentang jenis granola yang ditujukan untuk berbagai tujuan pasar terutama pasar-pasar induk yang sebagian besar untuk konsumen rumah tangga; dan (2) Pola Kemitraan Kelompok Tani atau Petani dengan PT. Indofood FM untuk komoditas kentang atlantik untuk memenuhi pabrik pengolahan keripik milik perusahaan mitra.

Pada pola pemasaran pada umumnya petani kentang granola di Bandung Jawa Barat menjual hasil produksinya melalui pedagang pengumpul desa atau antar desa/tengkulak (70 persen) dan pada petani berlahan luas serta memiliki modal dapat langsung menjual hasil kentangnya ke pedagang antarkota (20 persen), serta sebagian lagi menjualnya ke pasar induk serta pasar lokal kabupaten terdekat (10 persen). Dari pedagang besar antar kota, kentang didistribusikan ke beberapa tujuan pasar lainnya seperti: Pasar Induk Kramat Jati (Jakarta), Pasar Induk Cibitung (Bekasi), Pasar Induk Tangerang, Pasar Induk Bogor, dan Pasar Induk Caringin (Bandung) dengan pangsa 70 persen, pasar luar kota kabupaten dengan pangsa 20 persen, dan pasar lokal Kabupaten (Bandung, Garut, Tasikmalaya) dengan pangsa 10 persen.

Saluran tataniaga kentang pola pemasaran asal Kabupaten Bandung Jawa
Barat secara umum dapat disimak pada Gambar 1. Pada bagan tersebut nampak terdapat aliran komoditas kentang yang masuk dari daerah sentra produksi di luar Jawa Barat, terutama pada saat-saat produksi kurang dan atau permintaan tinggi, terutama dari daerah Dieng, Wonosobo, Jawa Tengah dan Malang, Jawa Timur. Dalam kondisi harga tinggi juga masuk kentang dari daerah sentra produksi lainnya seperti dari Sumatera Utara, Sumatera Barat, Jambi, Bengkulu, Bali, dan Sulawesi Selatan.

Harga yang diterima petani kentang Granola sesuai harga pasaran yaitu berkisar antara Rp2500 - Rp2800/kg. Harga ini relatif lebih rendah dibandingkan dengan harga jual kentang Atlantik.

Alur pemasaran kentang (varietas Atlantik) dari petani yang terwadahi kelompok tani langsung ke Perusahaan Mitra (PT IFM). Di Pangalengan dan Lembang Bandung produktivitas kentang Atlantik sekitar 18-20 ton/ha. Harga jual kontrak dengan PT IFM di tingkat petani Rp3800/kg, dan setelah diperhitungkan biaya-biaya pemasaran dan penyusutan serta fee kelompok maka harga bersih yang diterima petani sekitar Rp3300 - Rp3450/kg.

Pada usahatani kentang Atlantik, hasil analisis usahatani diperoleh tingkat perhektar sebesar $20.802 \mathrm{~kg}$, dan dengan tingkat harga sebesar Rp3.300/kg maka diperoleh penerimaan sebesar Rp68.882.164/ha/musim. Rataan total biaya usahatani yang dikeluarkan sebesar Rp39.829.639/ha/musim, dengan 
pengeluaran terbesar untuk bibit sebesar Rp16.898.517. Bibit kentang Atlantik diperoleh dari perusahaan mitra dan dibayar pada saat panen. Rataan keuntungan yang diperoleh sebesar Rp.29.052.525/ha/musim dan tingkat $\mathrm{R} / \mathrm{C}$ rasio sebesar 1,76 . Berikut ini disajikan alur pemasaran komoditas kentang varietas Atlantik pada petani yang menjalin kemitraan dengan PT Indofood FM. Dari alur ini, tampak rantai pemasaran komoditas kentang lebih pendek dan lebih efisien.

\section{Struktur Pasar}

Struktur pasar yang dihadapi petani komoditas kentang di Jawa Barat sangat ditentukan oleh penawaran dan permintaan pasar serta jumlah pelaku perusahaan yang bermain di dalam pasar atau industri. Untuk komoditas kentang atlatik karena hanya ada satu pembeli tunggal yaitu PT. IFM yang merupakan industri pengolahan keripik kentang (chiping) dalam berbagai jenis produk, dan dapat dikatakan berada dalam struktur pasar mendekati monopsoni, yaitu jumlah petani yang banyak (250 petani) berhadapan dengan satu PT. Indofood FM.

Secara umum dapat diketahui bahwa petani kentang (utamanya petani kentang granola) menghadapi struktur yang berbeda antar musim. Pada musim panen raya petani kentang di Jawa Barat menghadapi struktur pasar yang cenderung oligopsonistik dan pada musim panen biasa petani kentang menghadapi struktur pasar yang relatif bersaing, karena masuknya pedagang besar di daerah tujuan pasar yang masuk ke daerahdaerah sentra produksi. Struktur pasar oligopsonistik yang dihadapi petani tersebut dicirikan oleh beberapa hal sebagai berikut: (1) jumlah pedagang relatif terbatas; (2) harga ditentukan oleh pedagang besar antar kota dan pedagang besar ditujuan pasar utama, terutama pasar induk; (3) proporsi nilai tambah atau keuntungan yang diterima petani cenderung jatuh pada saat musim panen raya; (4) proporsi keuntungan yang diterima pelaku tataniaga relatif besar; (5) seringkali dalam satu kawasan sentra produksi kentang hanya beberapa pedagang yang sangat berpengaruh, dialah sebagai leading traders.

\section{Margin Pemasaran}

Margin pemasaran menggambarkan perbedaan harga yang dibayarkan konsumen dengan harga yang diterima produsen. Termasuk dalam margin tersebut adalah seluruh biaya pemasaran (marketing cost) yang dikeluarkan oleh lembaga tataniaga mulai dari gerbang petani sampai konsumen akhir dan keuntungan pemasaran (net profit margin) yang merupakan balas jasa dari pelaku tataniaga dalam menjalankan fungsi pemasaran. 
Net margin pemasaran untuk komoditas kentang atlantik meskipun menghadapi struktur pasar monopsoni namun ternyata petani menerima harga yang lebih tinggi dibandingkan dengan komoditas kentang varietas granola dengan struktur pasar yang relatif kompetitif, namun net margin pemasaran komoditas kentang granola secara keseluruhan lebih besar. Hal ini antara lain disebabkan oleh: (1) Perusahaan industri pengolahan PT IFM masih beroperasi di bawah kapasitas produksinya baik pabrik yang ada di Tangerang, apalagi dengan dibukanya pabrik baru di Semarang; (2) PT IFM sebagai perusahaan mitra melakukan differensiasi produk dan memperluas tujuan pasar hingga ekspor ke Singapura, Malaysia, Brunai Darussalam; (3) Petani melakukan konsolidasi melalui kelembagaan kelompok tani yang cukup rapi melalui perencanaan luas tanam dan luas panen secara teratur, sehingga memiliki bargaining posisition yang relatif seimbang; dan (4) petani juga memiliki alternatif menanam komoditas sayuran lainnya (kentang granola, tomat, cabe merah, bawang daun, kol/kubis, wortel), apabila tidak tercapai kesepakatan harga dipandang layak.

Net margin pemasaran yang diraih pada kegiatan pemasaran kentang Atlantik (kelompok tani) sebesar Rp 200/Kg. Sementara, net margin pemasaran kentang granola yaitu pada pedagang pengumpul desa sebesar $\mathrm{Rp} 150 / \mathrm{Kg}$ dan pada pedagang besar sebesar Rp200/Kg. Informasi tentang margin pemasaran dapat disimak pada Tabel 3.

\section{KESIMPULAN}

1. Di Kabupaten Bandung, areal kentang dalam kurun waktu 1999-2004 menunjukkan penurunan sebesar 7,64 persen/ tahun, yang diikuti oleh penurunan produksinya sebesar 7,48 persen, namun produktivitasnya masih bisa meningkat meskipun hanya sebesar 0,09 persen/tahun. Pada tahun 2004, areal panen kentang di Kabupaten Bandung sebesar 13.455 hektar dengan tingkat produksi dan produktivitasnya sebesar 261.388 ton dan 194,27 ku/ha. Fluktuatifnya luas areal panen komoditas kentang terutama jenis granola antara lain disebabkan: (1) meningkat-

Tabel 3. Tingkat Perolehan Rata-rata Marjin Pemasaran pada Beberapa Level Pedagang untuk Komoditas Kentang di Lokasi Penelitian Jawa Barat, 2006

\begin{tabular}{lcccc}
\hline \multicolumn{1}{c}{ Uraian } & $\begin{array}{c}\text { Harga beli } \\
(\mathrm{Rp} / \mathrm{kg})\end{array}$ & $\begin{array}{c}\text { Harga jual } \\
(\mathrm{Rp} / \mathrm{kg})\end{array}$ & $\begin{array}{c}\text { Margin } \\
\text { pemasaran } \\
(\mathrm{Rp} / \mathrm{kg})\end{array}$ & $\begin{array}{c}\text { Net Margin } \\
\text { Pemasaran } \\
(\mathrm{Rp} / \mathrm{kg})\end{array}$ \\
\hline $\begin{array}{c}\text { A. Pola kemitraan } \\
\text { (kentang Atlantik) } \\
\text { 1. Kelompok tani }\end{array}$ & 3400 & 3800 & 400 & 200 \\
$\begin{array}{l}\text { B. Pola bebas } \\
\text { (kentang Granola) } \\
\text { 1. Pedagang pengumpul } \\
\text { desa }\end{array}$ & 2500 & 2900 & & \\
2. Pedagang besar & 2500 & 3000 & 500 & 150 \\
\hline
\end{tabular}


nya harga input usahatani ; (2) serangan hama penyakit yang cukup beragam; dan (3) harga kentang relatif stabil bahkan cenderung menurun (granola), akibatnya petani melakukan pilihan jenis tanaman, sistem tanam, dan pola tanam.

2. Secara umum terdapat dua jenis varietas kentang yang diusahakan petani di Kabupaten Bandung, yaitu kentang Granola dan Atlantik. Kentang granola diusahakan oleh para petani pada umumnya secara mandiri, dan jenis kentang atlantik diusahakan oleh petani melalui kemitraan usaha dalam hal pemasaran dengan PT. Indofood FM dengan mediasi pedagang pengepul atau kelompok tani.

3. Terdapat dua pola saluran pemasaran komoditas kentang yang masih berjalan di Jawa Barat, yaitu: (1) Pola pemasaran untuk komoditas kentang jenis granola yang ditujukan untuk berbagai tujuan pasar terutama pasar-pasar induk yang sebagian besar untuk konsumen rumah tangga; dan (2) Pola Kemitraan Kelompok Tani atau Petani dengan PT. Indofood Fritolay Makmur untuk komoditas kentang atlantik untuk memenuhi pabrik pengolahan keripik milik perusahaan mitra.

4. Pada pola pemasaran pada umumnya petani kentang granola di Bandung Jawa Barat menjual hasil produksinya melalui pedagang pengumpul desa atau antar desa/tengkulak (70 persen) dan pada petani berlahan luas serta memiliki modal dapat langsung menjual hasil kentangnya ke pedagang antar kota (20 persen), dan sebagian lagi menjualnya ke pasar induk serta pasar lokal kabupaten terdekat (10 persen). Dari pedagang besar antar kota, kentang didistribusikan ke beberapa tujuan pasar lainnya. Harga yang diterima petani kentang Granola sesuai harga pasaran yaitu berkisar antara Rp2500Rp2800/kg. Harga ini relatif lebih rendah dibandingkan dengan harga jual kentang Atlantik.

5. Alur pemasaran kentang Atlantik dari petani yang terwadahi kelompok tani langsung ke Perusahaan Mitra (PT IFM). Harga jual kontrak dengan PT IFM di tingkat petani Rp 3800/kg, dan setelah diperhitungkan biaya-biaya pemasaran dan penyusutan serta fee kelompok maka harga bersih yang diterima petani sekitar Rp3300Rp3450/kg. Dengan demikian, dengan adanyanya kerjasama kemitraan maka petani memperoleh harga yang lebih tinggi dibanding dengan mengusahakan kentang tanpa kerjasama kemitraan.

6. Net margin pemasaran pada komoditas kentang atlantik meskipun menghadapi struktur pasar monopsoni namun ternyata petani menerima harga yang lebih tinggi dibandingkan dengan komoditas kentang varietas granola dengan struktur pasar yang relatif kompetitif, namun margin pemasaran komoditas kentang granola secara keseluruhan lebih besar. Net margin pemasaran yang diraih pada kegiatan pemasaran kentang Atlantik (kelompok tani) sebesar Rp200/Kg. Sementara, net margin pemasaran kentang granola yaitu pada pedagang pengumpul desa sebesar Rp150/Kg dan pada pedagang besar sebesar Rp200/ $\mathrm{Kg}$. 


\section{DAFTAR PUSTAKA}

Badan Pusat Statistik (2004). Bandung dalam Angka. Bandung: Badan Pusat Statistik Kabupaten Bandung

Badan Pusat Statistik (2006) Jawa Barat dalam Angka. Bandung: Badan Pusat Statistik Propinsi Jawa Barat.

Dinas Pertanian Bandung. (2004). Laporan Tahunan 2004. Bandung: Dinas Pertanian Tanaman Pangan Pemerintah Kabupaten Bandung.

Dinas Pertanian Jawa Barat. (2004-2006). Laporan Tahunan 2004-2006. Bandung: Dinas Pertanian Tanaman Pangan Pemerintah Propinsi Jawa Barat.

Irawan, et al., (2001). Kebijaksanaan Pengembangan Agribisnis Komoditas
Unggulan Hortikultura. Pusat Penelitian dan Pengembangan Sosial Ekonomi Pertanian. Bogor: Badan Penelitian dan Pengembangan Pertanian.

Kuma'at, R. (1995). Sistem Pemasaran Sayuran Dataran Tinggi di Propinsi Sulawesi Utara. Thesis Pascasarjana-IPB. Bogor.

Maliati, N. (2002). Kelembagaan Pemasaran Pertanian: Permasalahan, Tantangan, dan Alternatif Solusinya. Jakarta: Usese.

Winarno, (2002). Pengembangan Agribisnis Tanaman Buah TA 2002, dalam Pros. Pertemuan Nasional Hortikultura 24-27 September 2001. Jakarta. 